\title{
First Record of Atelerix albiventris (Family: Erinaceidae) from South-Eastern of Egypt Confirmed by Molecular Analysis
}

\author{
Lamiaa Elsayed Mokhtar Deef \\ Department of Zoology, Faculty of Science, Damietta University, New Damietta, \\ Damietta, Egypt
}

\begin{abstract}
A B S T RA C T
Atelerix albiventris or the four-toed hedgehog is here reported for the first time from the south-eastern of Egypt (Gebel Elba). This species is greatly distributed across central and eastern Africa. The exact identification of species is fundamental for an efficient assessment of changes related to the appearance of non-native species in an environment. The biometrics and molecular markers were used to confirm the identification of $A$. albiventris at the species level. In the current work $757 \mathrm{bp}$ and $668 \mathrm{bp}$ were identified as regions of the mitochondrial cytochrome b ( Cyt b) and mitochondrial 12S rRNA genes, sequences of both genes were placed in the GenBank publication database (Accession numbers are KF783143 and KJ193305) and (Accession numbers are M95109, KF783175, AC175224 and AC160876) of Cyt b and 12S rRNA respectively. Furthermore, DNA barcoding is a widely used molecular-based identification system which aids in identifying species.
\end{abstract}

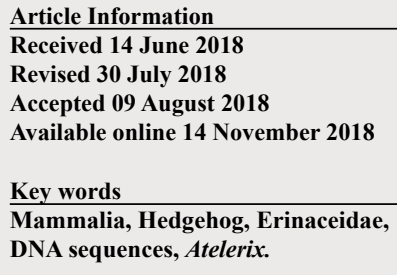

\section{INTRODUCTION}

$\mathrm{T}$ he hedgehogs are a group of mammals amongst the most familiar and distinctive insectivores. They are included in the order Eulipotyphla and family Erinaceidae. Family Erinaceidae (Erinaceinae) is one of the most widespread and diverse mammalian families in Egypt where it includes four species and two subspecies that are belonging to three genus. The genus Atelerix includes two species; the first is Atelerix algirus (Lereboullet, 1842) or the North African Hedgehog and it lives in El Negila, Matruh Governorate (Saleh and Basuony, 2014) and the second species is Atelerix albiventris (Wagner, 1841) or the four-toed hedgehog which is here reported for the first time from the south-eastern of Egypt in this study.

The four-toed African hedgehog (Atelerix albiventris) is the smallest one of the African hedgehogs for the genus Atelerix. This mammalian species is terrestrial, placental mammal and nocturnally active. It was classified as 'least concern' species on the international union for conservation of nature (IUCN) Red data list (Hutterer, 2008). The species is commonly found in suitable habitat but scarcely seen (Happold, 1987). A. albiventris is irregularly distributed throughout its range in eastern Africa (Easton, 1979).

\footnotetext{
* Corresponding author: lamiaadeef@yahoo.com; lamiaadeef@du.edu.eg 0030-9923/2019/0001-0009 \$ 9.00/0

Copyright 2019 Zoological Society of Pakistan
}

This species is widespread in West Africa, inhabiting steppes, savannas, and grassland (Happold, 1987; Easton, 1979). It can be found in human habitation, such as gardens, food stores, and cultivated fields (Reeve, 1994). According to Santana et al. (2010) and Happold (1987) this nocturnal insectivorous is sexually dimorphic and widespread. A. albiventris is insectivorous where their main diet contains insects, supplemented with small snakes, bird eggs, snails, amphibians, worms. They were need a diet with low in fat, high in protein, and must eat chitin which found in the exoskeletons of insects. A. albiventris has been domesticated and is used in biomedical research (Cansdale, 1960; Haltenorth and Diller, 1988; Graffam et al., 1998; Smith, 1999).

According to phylogenetic analyses of fossil and extant data, the Erinaceidae group may extend to the Late Cretaceous period (Gould, 1995). Erinaceidae contained almost 40 extinct forms in the super family Erinaceodea and was widely spread in Africa during the Miocene (Butler, 1969). Butler (1969) reported that, six species were found in East African Miocene deposits which they belonging to four genera. In Egypt only two species were found, A. algirus and the newly recorded A. albiventris. Morales and Rofes (2007) suggested that, A. algirus has been identified in a Bronze Age gravesite on the island of Minorca. A. albiventris has not any known fossil.

A. albiventris are live 5-7 years and 5-7in long, ovalbodied mammals, coat of spines is covered it. Its colour was varying from light tan to dark brown. Their faces 
are covered in white soft fur and its bellies. Spines range between $1 / 4$ and $3 / 4$ inch long and unlike porcupine quills, they have no barbs on the tips. They have small, round, and gleaming eyes, long snouts, and short legs. Absence of a hallux is the most important character which distinguishes A. albiventris than other species in the genus Atelerix (Kingdon, 1974). On the other hand, a small bony mass may be existent in place of the hallux in other species, or a well-developed toe may be on the hind feet especially. It characterizes also by a maxilla that has a common suture with nasals. According to the previous studies, this erinaceid is the smallest one of African hedgehog. Both North African hedgehog (A. algirus) and southern African hedgehog (Atelerix frontalis) have larger body size than $A$. albiventris. Undersides and legs of other Atelerix frontalis are darker than $A$. albiventris. A. albiventris has shorter ears than A. algirus. In all members of Atelerix, a white fur was found on the forehead (Reeve, 1994). It has 36 brachyodontic teeth: $2(3 / 2,1 / 1,3 / 2,3 / 3)$ with the first incisors being longer than the rest (Wozniak-Biel et al., 2015).

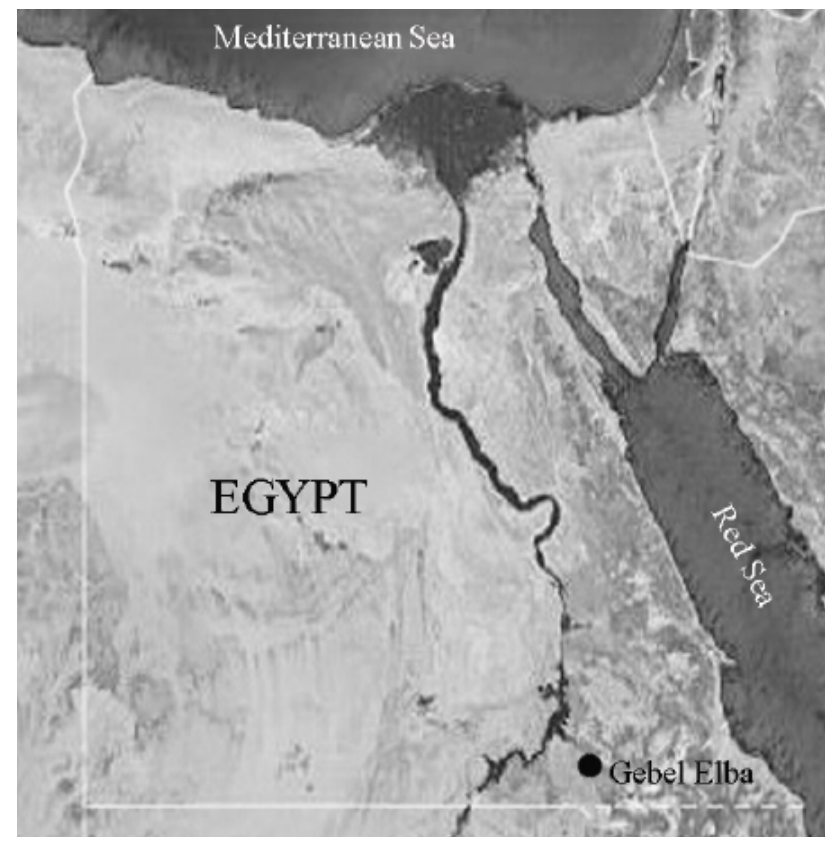

Fig. 1. Map of Egypt showing locality of Atelerix albiventris at Gebel Elba of the south-eastern Egypt.

DNA barcoding (DBC) is a system for taxonomic identification of animals instead of classical taxonomic methods that could become an effective tool for hedgehog conservation. DNA barcoding can be considered as a standardized technique for the characterization of life forms in different groups of living organisms (Yoo et al.,
2006; Hajibabaei et al., 2007) and the identification of new species (Yang et al., 2010). DNA barcodes can help in the routine identification of species in applied settings, in the detection of morphologically cryptic species, for host-specific lineages, and in the association of morphologically distinct life cycle forms within a species. In this study, two mitochondrial genes Cyt $\mathrm{b}$ and 12S rRNA were used as a popular bio-identification system. The sequence was resembled barcode with species being delineated by an appointed sequence of very similar sequences. Hence, in the present work, an attempt was done to study Atelerix albiventris, which is a new record from south-eastern of Egypt through molecular taxonomical profile of mitochondrial DNA cytochrome $b$ and $12 \mathrm{~S}$ ribosomal RNA genes.

\section{MATERIALS AND METHODS}

\section{Study area and sample collection}

Gebel Elba is a remote place in the south-eastern of Egypt, where Elba mountain blossoms on one side and a network of small valley and red sea hill are situated on other side, separating the red sea coast from the southernmost mountain of Egypt, Elba mountain. It is considered a biodiversity laden land which encompasses various ecosystems ranging from marshes, coastal plains, mangroves and coral reefs to mountain high lands, sand dunes and valley including many plants, fish, mammal and bird species.

The African pygmy hedgehog (A. albiventris) was collected from Gebel Elba of the south-eastern of Egypt at Lat. $22^{\circ} 23^{\prime} \mathrm{N}$ and Long. $35^{\circ} 48^{\prime} \mathrm{E}$, using GPS coordinates method (Fig. 1). Various means of obtaining specimens were used; trapping, digging out of burrows and netting at night under a spotlight or captured by hand while it crosses roads at night. Four specimens were collected from the location and kept alive then transferred to the laboratory. One of specimens AMDZ 2016 - 210 was euthanized and deposited in the mammals collections of Department of Zoology, Faculty of Science at Damietta University. Five external measurements were used to characterize the specimens: body mass (BM) in g, body length (BL), tail length (TL), hind foot length (HFL) and ear length (EL) in $\mathrm{mm}$. The following eight cranial measurements were taken to the nearest $0.01 \mathrm{~mm}$ using digital calipers: braincase width $(\mathrm{BCW})$, condylobasal length $(\mathrm{CBL})$, nasal length (NL), postorbital width (POW), greatest length of right posterior palatine foramen (PPF), rostral width (RW), skull height $(\mathrm{SH})$ and greatest zygomatic width $(\mathrm{ZW})$.

\section{DNA extraction PCR amplification and sequencing}

Muscle tissue was obtained from each sample. These samples were then preserved in $95 \%$ alcohol and 
stored in deep freezer at $-4^{\circ} \mathrm{c}$, where the hedgehog's DNA was extracted using a GeneJET ${ }^{\mathrm{TM}}$ kit Genomic DNA Kit\#K0721 following manufacturer's recommendations.

Cyt $b$ gene was amplified using primers FE1 (5'CCA TTG TTG TAA YTC AAC T-3') and RE1 (5'- GAT TGA TCG RAG AAT TGC-3') and mitochondrial 12S rRNA primers EF (5'- AGC CAC CGC GGT CAT ACG A-3') and ER (5'- GTA TAC TTA CCT TGT TAC G-3'). The polymerase chain reactions (PCR) consisting of approximately $50 \mathrm{ng}$ of template DNA were carried out in volumes of $15 \mu \mathrm{l}$ with $1 \times$ PCR Buffer, $2 \mathrm{mM} \mathrm{MgCl}, 0.5$ $\mu \mathrm{M}$ of each FE1 and RE1, $0.2 \mathrm{mM}$ of dNTP, and $0.6 \mathrm{U}$ of Taq DNA Polymerase. The thermal programme of Cyt $b$ primers started with an initial denaturation at $95^{\circ} \mathrm{C}$ for 15 min, followed by 45 cycles of $40 \mathrm{~s}$ at $94^{\circ} \mathrm{C}, 30 \mathrm{~s}$ at $60^{\circ} \mathrm{C}, 1$ min at $72^{\circ} \mathrm{C}$, and a final extension of $7 \mathrm{~min}$ at $72^{\circ} \mathrm{C}$. In case of $12 \mathrm{~S}$ rRNA primers, the Thermal programme started with an initial denaturation at $94^{\circ} \mathrm{C}$ for $2 \mathrm{~min}$, followed by 45 cycles of denaturation at $94^{\circ} \mathrm{C}$ for 45 seconds, annealing at $55^{\circ} \mathrm{C}$ for $1 \mathrm{~min}$ and extension at $72^{\circ} \mathrm{C}$ for $1 \mathrm{~min}$, with a final extension for $20 \mathrm{~min}$ at $72^{\circ} \mathrm{C}$.

PCR products were visualized in a $2.0 \%$ agarose gel stained with ethidium bromide, and photographed under UV transillumination. PCR products were purified using a GeneJET ${ }^{\mathrm{TM}}$ kit (Thermo K0701) according to the manufacturer's protocol. Purified PCR samples were sent for sequencing to a GATC Company in England who uses an ABI 3730xl DNA sequencer.

\section{Molecular analysis}

The resulting sequences were confirmed as being derived from the four-toed hedgehog DNA using the GenBank Blast algorithm. The DNADynamo software version 1.459 was used for editing the sequences and they were aligned using Clustal W. Finally, the phylogenetic analyses used were Maximum Likelihood (ML) in MEGA 6.0 software (Tamura et al., 2013).

\section{RESULTS}

\section{Morphological data}

The four-toed hedgehog has splotchy black and white body with no dorsal stripe. It is spiny and small with pointed muzzle. A. albiventris distinguishes by black eyes and large dark ears (Fig. 2). The tail is short and covered thinly with hair. The feet are dark and also covered with hair. Unlike related species, the four-toed hedgehog lacks the hallux and has only four toes on each foot as its common name implies.

A. albiventris has spines without barbs. The longest spines of the body are on the head while the whole body, except the cranial-caudal tract is covered dorsally with short spines. Spines are white at the base and tips with a central band that varies in width and color. Many elongated white spines are characterizing males that usually are absent in females. A. albiventris has no spines on the venter which has a white colour. Females are larger than males in the studied hedgehog.

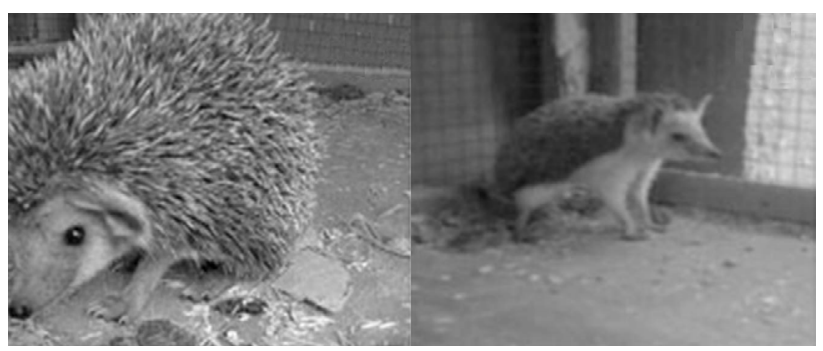

Fig. 2. Atelerix albiventris (Wagner, 1841) observed at Gebel Elba of the south-eastern Egypt.

The mean external measurements of these specimens were; body mass (BM), weighing between 400 and $520 \mathrm{~g}$; body length (BL), between 200 and $240 \mathrm{~mm}$; tail length (TL), around $20 \mathrm{~mm}$; head and body length (HBL), 230.3 $\mathrm{mm}$; hind foot length (HFL), $30 \mathrm{~mm}$ and ear length (EL), 27 $\mathrm{mm}$. A albiventris has a small skull (condylobasal length (CBL), $44.2 \mathrm{~mm}$ ) with a broad posterior palatal shelf; the postglenoid process is smaller than the mastoid process. A zygomatic arch is present, greatest zygomatic width (ZW), $27.9 \mathrm{~mm}$. Braincase width (BCW), $19.8 \mathrm{~mm}$; nasal length (NL), $16.4 \mathrm{~mm}$; postorbital width (POW), $11.4 \mathrm{~mm}$; greatest length of right posterior palatine foramen (PPF), 6 $\mathrm{mm}$; rostral width (RW), $11.2 \mathrm{~mm}$ and skull height $(\mathrm{SH})$, $11.6 \mathrm{~mm}$. Third upper premolar is either absent or reduced. Molar teeth are blunt and broad.

\section{Sequencing analysis}

The cytochrome $b$ gene sequences were corresponded with data stocked in National Centre of Biotechnological Information (NCBI) by nucleotide BLAST. The sample was identified as $757 \mathrm{bp}$ in length and exhibited similarity with Cyt $\mathrm{b}$ gene of $A$. albiventris from GenBank database. The sequences were compared with records deposited in GenBank, the results revealed entirely similar records (Accession numbers are KF783143 and KJ193305) (Fig. 3). Moreover, sequences of $12 \mathrm{~S}$ rRNA gene were compared with records deposited in GenBank the results gave entirely similar records (Accession numbers are M95109, KF783175, AC175224 and AC160876) (Fig. 4). The sample was identified as $668 \mathrm{bp}$ in length and exhibited similarity with $12 \mathrm{~S}$ rRNA gene of $A$. albiventris from GenBank database. A. albiventris have no agreed universally subspecies. 
Phylogenetic tree was constructed depending on Cyt b sequences of the four-toed hedgehog using Maximum Likelihood method. The tree shows that, A. albiventris is grouped in one clade with another compared sequences record deposited in GenBank of $A$. albiventris. In addition, the phylogenetic tree based on $12 \mathrm{~S}$ rRNA sequences of the studied hedgehog was performed in the current study using Maximum Likelihood method revealed that our new Egyptian $A$. albiventris belongs to the same clade with another stocked data of $A$. albiventris from GenBank database.

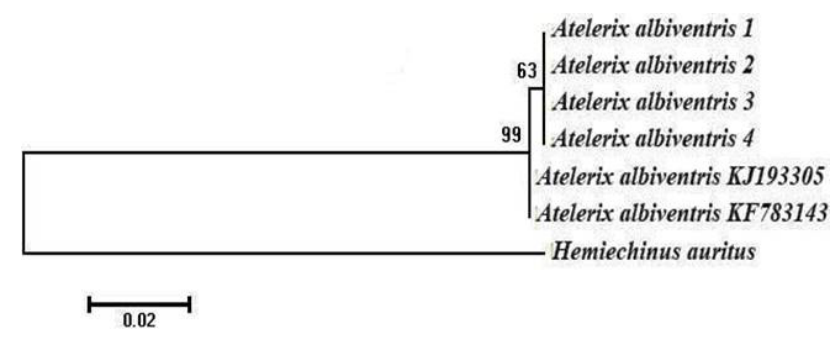

Fig. 3. Maximum likelihood (ML) phylogenetic tree based on Cyt b gene sequences of the studied hedgehog. Specimen's number denotes the accession number of NCBI database.

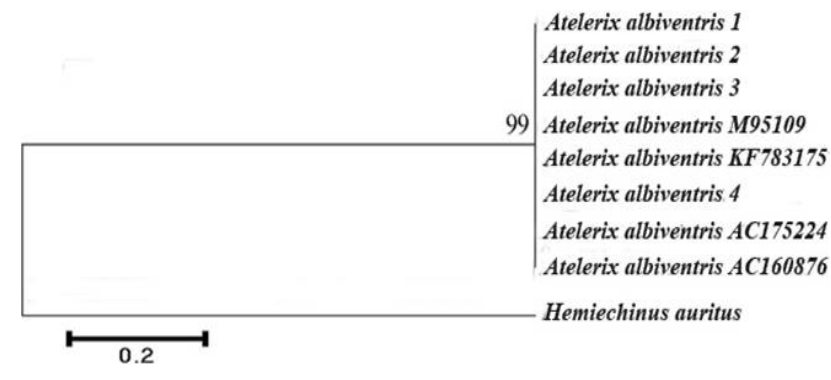

Fig. 4. Maximum likelihood (ML) phylogenetic tree based on 12S rRNA gene sequences of the studied hedgehog. Specimen's number denotes the accession number of NCBI database.

\section{DISCUSSION}

An ideal barcode should possess sufficient variation among the sequences to discriminate species; however, it also needs to be sufficiently conserved so that there is less variability within species than between species (Kress and Erickson, 2008). DNA barcoding employs sequences from a short standardised gene region to identify species (Hebert et al., 2010). Recent studies have shown that, sequence divergences are much larger among species than within species (Hebert et al., 2003); thus, analysis of DNA divergences could be used for species identification (Hebert et al., 2004). Barcoding, together with related developments in sequencing technology, is likely to provide an efficient approach for the assembly of such genetic data. DNA barcoding is a widely used molecular-based identification system which aids in identifying biological specimen. Ward et al. (2009) reported that, the simplest method of seeking the identification of an unknown specimen is to place its cytochrome b sequence into the "barcode of life database system" (BOLD) identification engine. In the present study, the cytochrome b (Cyt b) gene sequence was corresponding with hedgehog base which displayed $99 \%$ similarity value with $A$. albiventris from GenBank database. Consequently, in this study, $A$. albiventris was sequenced and mitochondrial cytochrome b gene can be greatly supported the efficacy of barcodes for identification. In addition, another mitochondrial gene sequences of $12 \mathrm{~S}$ rRNA were compared with records deposited in GenBank and exhibited similarity with 12S rRNA gene of $A$. albiventris from GenBank database (99\%).

The four-toed hedgehog is very widespread from Senegal across to Ethiopia and south to the Zambezi River (Hutterer, 2005). This mammalian species is distributed in the Masai Steppe in Tanzania (Kingdon, 1974), but rare in other areas of clearly suitable habitat (Easton, 1979). It is popular in the Lilongwe, Blantyre, and Mulanje areas. This hedgehog may be visible throughout Malawi but it does not come across often elsewhere (Ansell and Dowsett, 1988). Kingdon (1974) stated that African pygmy hedgehog is widely spread but sporadic in drier regions of Africa.

Haltenorth and Diller (1988) reported that $A$. albiventris occupies a variety of terrestrial habitats including grassland, scrub, savannah, suburban gardens, woodlands, bush, thickets, agricultural land (plantations, fields, and gardens), plains, and hills. These animals occur in suburban areas where it may occupy stables, food stores, and other buildings. They live in areas with dry soils and are absent from marshes and dense forests. Generally, this species requires dry shelters in matted grass, leaf litter, a rocky crevice, or a hole in the ground (Nowak, 1999).

Kingdon (1997) observed that A. albiventris occurs commonly in areas where it can sleep in termitaries, rock crevices, buildings, or under tangles of brushwood or dry leaf litter. Also, it is visible on well-drained soils and sandy region. These animals show a predilection for relatively open, dry, or seasonal habitats with sparse or patchy grass cover, especially overgrazed regions with dense populations of ungulates. These requirements are well met in suburban gardens and in many heavily grazed rangelands where there is an abundance of trampled herbage and dung to support termites and other insects.

For the first time, A. albiventris is recorded from Gebel Elba of the south-eastern of Egypt which no record of this 
hedgehog was known before in Egypt. The specimens from this region fit well with morphological diagnostic characters of $A$. albiventris. Besides morphology, morphological and cranial measurements are in agreement with Happold (1987), Allen (1922) and Santana et al. (2010) which aid in identifying this hedgehog. In light of the previous results, morphological characteristics, measurements and using of genetic sequencing technology were confirmed that the hedgehog is A. albiventris. Presence of the African pygmy hedgehog in an unexpected area and contrary to the usual environment in which to live where it tends to live in the grasslands, but a recording of this hedgehog in the mountainous region may be due to climatic or environmental changes or perhaps human activities. Therefore, it may be useful to conduct future studies on $A$. albiventris ecology to clarify the reasons for its appearance in this region.

\section{CONCLUSIONS}

This study provides the first sighting record of A. albiventris (the four-toed hedgehog, mammalian: Erinaceidae) from south-eastern of Egypt. The mammal fauna of Egypt is characterized by high levels of endemism. The exotic $A$. albiventris may have been affecting native mammals in Egypt. It is strongly recommended that, intensive surveys be made of distribution of $A$. albiventris in Egypt to estimate the effect of this hedgehog on the native small mammals there. These surveys will be useful to protect the biodiversity of mammals in these regions. Furthermore, DNA barcoding is a widely used molecularbased identification system which aids in identifying species.

\section{Ethics approval and consent to participate}

All animal experiments involved in this study were approved by the Laboratory Animal Welfare and Animal Experimental Ethical Committee of IACUC Cairo University. We followed guidelines of the Committee for experimental animals during this study.

\section{Statement of conflict of interests}

Author has declared that no competing interests exist.

\section{REFERENCES}

Allen, J.A., 1922. The American Museum Congo expedition collection of insectivora. Bull. Am. Mus. Nat. Hist., 47: 1-38.

Ansell, W.F.H. and Dowsett, R.J., 1988. Mammals of Malawi: An annotated checklist and atlas. Trendine Press, Saint Ives, Cornwall, United Kingdom.
Butler, P.M., 1969. Insectivores and bats from the Miocene East Africa: New material. In: Fossil vertebrates of Africa (ed. L.S.B. Leakey). Academic Press, New York, pp. 1-37.

Cansdale, G.S., 1960. Animals of West Africa. Longmans, Green \& Company, London, United Kingdom.

Easton, E.R., 1979. Observations on the distribution of the hedgehog Erinaceus albiventris in Tanzania. Afri. J. Ecol., 17: 175-176. https://doi. org/10.1111/j.1365-2028.1979.tb00253.x

Gould, G.C., 1995. Hedgehog phylogeny (Mammalia: Erinacedae): the reciprocal illumination of the quick and the dead. Am. Mus. Novit., 3131: 1-45.

Graffam, W.S., Fitzpatrick, M.P. and Dierenfeld, E.S., 1998. Fiber digestion in the African white-bellied hedgehog (Atelerix albiventris): A preliminary evaluation. J. Nutr., 128: 2671S-2673S. https://doi. org/10.1093/jn/128.12.2671S

Hajibabaei, M., Singer, G.A., Clare, E.L. and Hebert, P.D., 2007. Design and applicability of DNA arrays and DNA barcodes in biodiversity monitoring. BMC Biol., 5: 1-7. https://doi.org/10.1186/17417007-5-1

Haltenorth, T. and Diller, H., 1988. The Collins field guide to the mammals of Africa including Madagascar. Stephen Green Press, Lexington, Massachusetts.

Happold, D.C.D., 1987. The mammals of Nigeria. Clarendon Press, Oxford.

Hebert, P.D., Cywinska, A., Ball, S.L. and de Waard, J.R., 2003. Biological identifications through DNA barcodes. Proc. biol. Sci., 270: 313-321. https://doi. org/10.1098/rspb.2002.2218

Hebert, P.D., Stoeckle, M.Y., Zemlak, T.S. and Francis, C.M., 2004. Identification of birds through DNA barcodes. PLoS Biol., 2: e312. https://doi. org/10.1371/journal.pbio.0020312

Hebert, P.D., de Waard, J.R. and Landry, J.F., 2010. DNA barcodes for $1 / 1000$ of the animal kingdom. Biol. Lett., 6: 359-362. https://doi.org/10.1098/ rsb1.2009.0848

Hutterer, R., 2005. Order Erinaceomorpha. In: Mammal species of the world: A taxonomic and geographic reference, $3^{\text {rd }}$ ed. (eds. D.E. Wilson and D.M. Reeder). Johns Hopkins University Press, Baltimore, Maryland, pp. 212-219.

Hutterer, R., 2008. Atelerix albiventris. International Union for Conservation of Nature and Natural Resources red list of threatened species. https:// doi.org/10.2305/IUCN.UK.2008.RLTS. T40602A10337084.en 
Kingdon, J., 1974. East African mammals: An atlas of evolution in Africa, Vol. 2A. Academic Press, London, United Kingdom.

Kingdon, J., 1997. The kingdon field guide to African mammals. Academic Press, San Diego, California.

Kress, W.J. and Erickson, D.L., 2008. DNA barcodes: Genes, genomics, and bioinformatics. Proc. natl. Acad. Sci. USA, 105: 2761-2762. https://doi. org/10.1073/pnas.0800476105

Morales, A. and Rofes, J., 2007. Early evidence for the Algerian hedgehog in Europe. J. Zool., 274: 9-12. https://doi.org/10.1111/j.1469-7998.2007.00349.x

Nowak, R.M., 1999. Walker's mammals of the world, $6^{\text {th }}$ ed. Johns Hopkins University Press, Baltimore, Maryland.

Reeve, N., 1994. Hedgehogs. T \& AD Poyser Limited, London, United Kingdom.

Saleh, M.A. and Basuony, M.I., 2014. New mammalian records from Egypt. Egypt. J. Zool., 62: 1-40. https://doi.org/10.12816/0009339

Santana, E.M., Jantz, H.E. and Best, T.L., 2010. Atelerix albiventris (Erinaceomorpha: Erinaceidae). Mammal. Sp., 42: 99-110. https://doi. org/10.1644/857.1

Smith,A.J., 1999. Husbandry and nutrition of hedgehogs:
Veterinary clinic of North America. J. Small Anim. Pract., 2: 127-141. https://doi.org/10.1016/S10949194(17)30143-3

Tamura, K., Stecher, G., Peterson, D., Filipski, A. and Kumar, S., 2013. MEGA6: Molecular evolutionary genetics analysis, version 6.0. Mol. Biol. Evol., 30: 2725-2729. https://doi.org/10.1093/molbev/mst197

Ward, R.D., Hanner, R. and Hebert, P.D.N., 2009. Review paper: The campaign to DNA barcode all fishes. J. Fish Biol., 74: 329-356. https://doi. org/10.1111/j.1095-8649.2008.02080.x

Wozniak-Biel, A., Janeczek, M., Janus, I. and Marcin, N.M., 2015. Surgical resection of peripheral odontogenic fibromas in African pygmy hedgehog (Atelerix albiventris): A case study. BMC Vet. Res., 11: 145-148. https://doi.org/10.1186/s12917-0150455-0

Yang, R., Wu, X., Yan, P. and Li, X., 2010. Using DNA barcodes to identify a bird involved in a birdstrike at a Chinese airport. Mol. Biol. Rep., 37: 35173523. https://doi.org/10.1007/s11033-009-9945-0

Yoo, H.S., Eah, J.Y., Kim, J.S., Kim, Y.J., Min, M.S., Paek, W.K., Lee, H. and Kim, C.B., 2006. DNA barcoding Korean birds. Mol. Cells, 22: 323-327. 